\title{
Pemberdayaan PKK Desa Pagarawan melalui Budi Daya Tanaman Sayuran dengan Sistem Hidroponik
}

\section{(Empowerment of PKK Pagarawan Village through Cultivation Vegetables with Hydroponics Systems)}

\author{
Eries Dyah Mustikarini*, Ratna Santi, Ismed Inonu \\ Program Studi Agroteknologi, Fakultas Pertanian Perikanan dan Biologi, Universitas Bangka Belitung, \\ Jl. Raya Balunijuk, Kampus Terpadu UB, Balunijuk, Merawang, Bangka Belitung 33172. \\ *Penulis Korespondensi: eriesdyah@yahoo.com \\ Diterima Januari 2019/Disetujui Juli 2019
}

\begin{abstract}
ABSTRAK
Budi daya sayuran secara hidroponik bagi ibu-ibu PKK bertujuan menghasilkan sayuran skala rumah tangga yang aman. Kegiatan ini menjadi peluang bagi masyarakat untuk menambah pendapatan. Kegiatan pengabdian dilaksanakan di Desa Pagarawan, Kecamatan Merawang, Kabupaten Bangka pada bulan Mei-Agustus 2018. Tujuan kegiatan pengabdian adalah untuk memberikan penyuluhan dan pelatihan tentang budi daya tanaman dengan sistem hidroponik. Jenis sayuran yang dibudidayakan adalah sawi. Sistem hidroponik yang disosialisasikan kepada peserta adalah sistem hidroponik terapung dan alir dengan menggunakan wick. Hasil survei terhadap peserta pelatihan didapatkan data $38,46 \%$ sangat setuju, $61,54 \%$ setuju, dan $0 \%$ tidak setuju untuk melakukan budi daya sayuran secara hidroponik. Hasil analisis SWOT menunjukkan untuk meningkatkan motivasi masyarakat dalam melakukan budi daya tanaman secara hidroponik perlu adanya modal/investasi, dukungan dari akademisi, dan pemerintah. Hasil analisis usaha tani tanaman sawi secara hidroponik membutuhkan modal awal Rp 2.016.000, keuntungan yang didapatkan Rp 502.570/bulan, dan modal usaha dapat kembali dalam waktu 4 bulan. Sistem tanaman hidroponik sangat bagus untuk dikembangkan karena selain bisa memnuhi kebutuhan sayur untuk rumah tangga juga dapat menambah penghasilan keluarga.
\end{abstract}

Kata kunci: Bangka, hidroponik, sayuran, SWOT, usaha tani

\begin{abstract}
Hydroponic vegetable cultivation for PKK mothers aims to produce safe household-scale vegetables. This activity was an opportunity for the community to increase income. Community service activities were carried out in Pagarawan Village, Merawang Subdistrict, Bangka District in May-August 2018. The purpose of community service activities was to provide counseling and training on plant cultivation with a hydroponic system. Kind of vegetables that are cultivated are mustard greens. The hydroponic system that was socialized to participants was a floating and flowing hydroponic system using a wick. The results of a survey to training participants showed that $38.46 \%$ strongly agreed, $61.54 \%$ agreed, and $0 \%$ disagreed with hydroponic vegetable cultivation. The results of SWOT analysis showed that to increased community motivation in conducting hydroponic crop cultivation there needs a capital/investment, support from academics, and the government. The results of analysis of mustard greens farming in hydroponics require an initial capital of IDR 2,016,000, a profit of IDR 502,570/month, and venture capital can be returned within 4 months. The hydroponic plant system is very good to be developed because besides being able to meet the needs of vegetables for the household it can also increase family income.
\end{abstract}

Keywords: Bangka, farming business, hydroponic, SWOT, vegetables

\section{PENDAHULUAN}

Pertambahan jumlah penduduk menyebabkan alih fungsi sebagian besar lahan pertanian. Desa Pagarawan terletak 11,5 km dari ibu kota provinsi dan berjarak 4,6 $\mathrm{km}$ dari kampus Universitas Bangka Belitung. Lahan-lahan pertanian di Desa Pagarawan banyak beralih fungsi menjadi pertokoan, kost, dan industri. Berdasarkan Desa Pagarawan (2018) saat ini hanya $1,85 \%$ penduduk yang bekerja sebagai petani. Masyarakat mulai mengalami kesulitan dalam mendapatkan bahan produksi pertanian segar dari kebun sendiri. Sistem hidroponik dapat dilakukan untuk mengatasi masalah lahan yang terbatas (Roidah 2014). Menurut Haryanto 
et al. (2002) hidroponik dapat dilakukan pada ruang atau tempat yang terbatas.

Sistem budi daya tanaman sayuran secara hidroponik ini tepat dikembangkan di Desa Pagarawan. Hal ini karena sebagian besar dari penduduk Desa Pagarawan tidak memiliki lahan pertanian. Menurut Tim Karya Tani Mandiri (2010) elemen dasar hidroponik yang dibutuhkan tanaman sebenarnya bukanlah tanah, tapi cadangan makanan serta air yang terkandung dalam tanah yang terserap akar berupa larutan unsur hara. Media untuk budi daya tanaman secara hidroponik dapat berupa pasir, rockwool, kerikil, perlit, sabut kelapa, serbuk gergaji, gambut, batu apung, kulit kacang, poliester, atau vermikulit (Resh 2013; Putra 2018).

Banyak tanaman yang dapat dibudidayakan secara hidroponik, seperti brokoli, cabai, kailan, melon, pakcoi, paprika, seledri, sawi, selada, timun, dan terong Jepang, serta tomat (Swastika et al. 2018). Sistem penanaman sayuran sawi dapat dilakukan secara hidroponik untuk menutupi berbagai kekurangan pada sistem budi daya secara konvensional di lahan. Teknologi hidroponik memiliki beberapa kelebihan di antaranya dapat dilakukan pada ruang atau tempat yang terbatas dan adanya efisiensi kerja kebun, menghemat ongkos perawatan dan peralatan pada media tanah biasa. Rahimah (2012) menambahkan keuntungan teknologi hidroponik antara lain dapat menghemat biaya investasi sekitar 38\%, mampu menghasilkan sayuran yang dipersyaratkan pasar, dan pemberian nutrisi yang sesuai membuat tanaman sehat sehingga lebih tahan terhadap serangan hama dan penyakit.

Kendala yang ditemukan dalam bertanam secara hidroponik adalah bahan dan media yang harus dibeli seperti perlit, zeolite, dan rockwool, serta sangat terbatasnya informasi yang pasti karena biasanya sistem yang digunakan adalah sistem coba-coba dan setiap tempat berbeda penanganannya (Sameto 2005; Azizah 2009). Tim Karya Tani Mandiri (2010) menambahkan, ketersediaan dan pemeliharaan perangkat hidroponik agak sulit, memerlukan keterampilan khusus untuk menimbang dan meramu bahan kimia dan investasi awal yang mahal.

Tujuan dari kegiatan pengabdian masyarakat ini adalah 1) Memperkenalkan kepada masyarakat tentang berbagai sistem budi daya sayuran secara hidroponik; 2) Memberikan pengetahuan pada masyarakat mengenai budi daya sayuran secara hidroponik dengan cara yang mudah dan murah; 3) Menumbuhkan motivasi kepada masyarakat untuk melakukan budi daya tanaman yang lebih sehat dan ekonomis di rumah masingmasing; dan 4) Menumbuhkan minat berbisnis masyarakat untuk meningkatkan pendapatan keluarga.

\section{METODE PELAKSANAAN KEGIATAN}

\section{Lokasi Kegiatan}

Kegiatan pengabdian masyarakat ini berlokasi di Desa Pagarawan, Kecamatan Merawang, Kabupaten Bangka, Provinsi Kepulauan Bangka Belitung. Kegiatan dilaksanakan bulan MeiAgustus 2018.

\section{Partisipan Kegiatan}

Khalayak sasaran adalah Tim Penggerak PKK Desa Pagarawan, Kecamatan Merawang, Kabupaten Bangka. Masyarakat Desa Pagarawan perlu diperkenalkan pada teknologi yang dapat digunakan untuk memenuhi kebutuhan sayursayuran secara berkesinambungan, sehat, dan bebas pestisida.

\section{Bahan dan Alat}

Alat yang digunakan adalah bak semai, dus styrofoam, pipa paralon, mesin air, besi pelubang dus, kompor pemanas, TSD/EC meter, gergaji kecil, gelas ukur, dan gunting. Bahan yang digunakan adalah plastik hitam, netpot, rockwool, kain flannel, steaples, botol bekas ukuran 1,5 l, isolasi, air, pupuk $\mathrm{AB}$ Mix, dan benih tanaman sawi.

\section{Metode Pelaksanaan Kegiatan}

Metode pengabdian masyarakat yang digunakan adalah share pengetahuan, pelatihan, dan pendampingan. Peserta terdiri dari 25 orang ibu-ibu Tim Penggerak PKK Desa Pagarawan yang berkeinginan mengikuti kegiatan yang dilaksanakan. Tahapan pelaksanaan kegiatan budi daya sayuran secara organik dilakukan tiga sesi, yaitu share pengetahuan dan praktik langsung di lapangan (pelatihan) dan pendampingan. Pelatihan yang dilakukan di antaranya pembuatan instalasi hidroponik dan langsung menanam sayuran sawi. Metode budi daya hidroponik mengikuti metode Susila (2013).

Kegiatan ini juga didukung oleh adanya percontohan instalasi hidroponik sistem alir menggunakan pipa paralon yang selanjutnya dihibahkan kepada kantor Desa Pagarawan. Percontohan lainnya adalah sistem hidroponik sederhana (wick) menggunakan dus styrofoam 
yang dipraktikkan bersama peserta dan dihibahkan kepada masing-masing peserta. Peserta pelatihan mendapatkan pendampingan dari pelatih dalam budi daya tanaman sayuran di media hidroponik. Kegiatan yang dilakukan meliputi persemaian, pembuatan media hidroponik, pengaplikasian nutrisi, penanaman, pemeliharaan tanaman, pemanenan, dan pascapanen (Gambar 1).

\section{Pengambilan dan Analisa Data}

Data kebutuhan modal, pengeluaran, dan pendapatan dari usaha hidroponik dilakukan dengan menghitung kebutuhan alat dan bahan, biaya penyusutan alat, dan nilai jual produk. Data tersebut digunakan untuk menentukan nilai Break Even Point (BEP), Return of Invesment, dan Benefit Cost Rasio, sehingga didapatkan waktu balik modal. Evaluasi kegiatan dilakukan pada setiap tahapan pelatihan/penyuluhan dan akhir kegiatan dengan menyebarkan kuesioner. Tingkat keberhasilan kegiatan akan dipelajari dengan analisis SWOT dan metode penyebaran kuesioner pada peserta pelatihan. Kegiatan ini dianggap berhasil jika $>50 \%$ peserta latihan berminat untuk menerapkan program

\section{HASIL DAN PEMBAHASAN}

\section{Kondisi Umum Pelaksanaan Kegiatan}

Anggota PKK Desa Pagarawan secara umum tidak bekerja atau hanya melakukan pekerjaan rumah saja, sehingga penghasilan mereka pun masih berkecukupan. Produksi tanaman sayuran organik bebas pestisida seperti pagoda dan pakcoy segar nilai jualnya juga berfluktuasi sesuai dengan kebutuhan masyarakat dunia akan produk tersebut. Berdasarkan data Badan Pusat Statistik Babel (2016) menunjukkan Kecamatan Merawang pada tahun 2015 masih ada 994 keluarga pra sejahtera, 4795 sejahtera 1, 3066 sejahtera 2, 5372 sejahtera 3, dan 13 yang tergolong sejahtera 3 plus. Perlu langkah kongkret untuk meningkatkan kesejahteraan masyarakat.

Hasil kegiatan pengabdian masyarakat di Desa Pagarawan menunjukkan bahwa ibu-ibu Tim Penggerak PKK Desa Pagarawan memiliki antusias cukup tinggi terhadap program pengabdian masyarakat yang ditawarkan. Sistem hidroponik yang diperkenalkan pada peserta adalah sistem alir menggunakan pipa paralon. Sistem ini merupakan sistem yang dapat mensirkulasi air dengan baik dengan bantuan pompa air sebagai sarana untuk menjalankan aliran air. Tanaman sayuran yang dibudidayakan, yaitu sawi. Sistem hidroponik selanjutnya, yaitu sistem wick yang difasilitasi dengan dus styrofoam dan kain flannel, serta tanpa menggunakan pompa sirkulasi air.

\section{Pelatihan Budi Daya Tanaman Sayuran dengan Sistem Hidroponik}

Kegiatan penyuluhan diawali dengan penyampaian materi hidroponik oleh pemateri. Penyampaian materi ini dilakukan untuk memberikan pamahaman kepada masyarakat secara teori. Pemahaman terhadap materi hidroponik sangat berpengaruh pada keterampilan dalam budi daya sayuran hidroponik untuk pemula. Penyampaian materi hidroponik selesai, dilanjutkan dengan demonstrasi pembuatan sistem hidroponik langsung di luar Kantor Desa Pagarawan (Gambar 2 dan 3).

Kegiatan budi daya sayuran organik dimulai dengan pemotongan rockwool, pemotongan kain flannel, persiapan media styrofoam (Gambar 4),

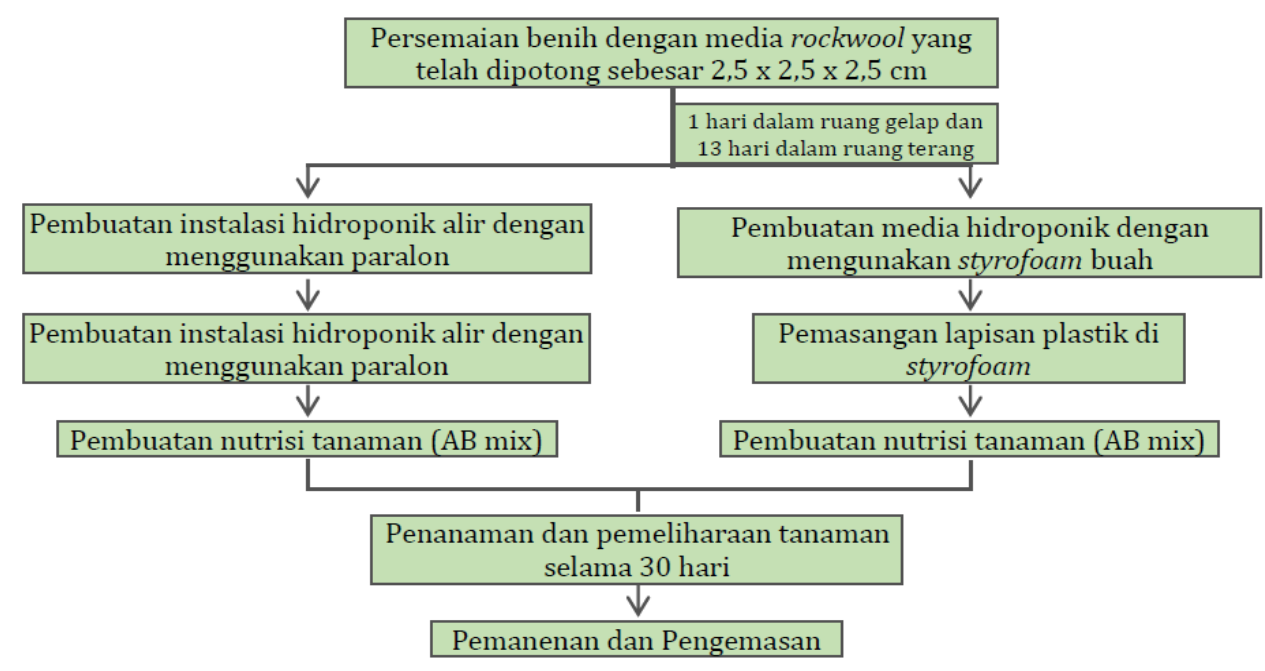

Gambar 1 Tahapan budi daya sayuran secara hidroponik. 
pembuatan dan pengaplikasian nutrisi $\mathrm{AB}$ mix, persemaian, penanaman (Gambar 5), pemeliharaan, pemanenan, dan pengemasan. Hasil budi daya dari sawi menunjukkan hasil yang cukup memenuhi kriteria sayuran organik segar tanpa pestisida. Hasil analisis SWOT menunjukkan masyarakat tertarik dengan kegiatan budi daya sayuran hidroponik di pekarangan rumah masing-masing. Hal ini terlihat dari antusias mereka untuk menanyakan berbagai informasi tentang teknik budi daya sayuran hidroponik yang tepat. Kegiatan pelatihan dilengkapi dengan kegiatan peninjauan lapangan oleh tim yang dilakukan setiap hari untuk melihat tingkat keberhasilan masyarakat dalam menanam sayuran hidroponik.

Hasil kegiatan pelatihan menunjukkan sebagian besar masyarakat Desa Pagarawan belum mengenal budi daya tanaman sayuran secara hidroponik. Persoalan utama yang dihadapi ketika akan dikembangkan sayuran hidroponik oleh masyarakat adalah keterbatasan biaya dan kurangnya keterampilan. Kegiatan budi daya tanaman sayuran hidroponik di Desa Pagarawan tersebut diawali dengan kegiatan pendampingan yang dilakukan oleh pelaksana dalam kegiatan ini. Kegiatan pendampingan melalui budi daya sayuran terus dilakukan hingga masyarakat terampil melakukan budi daya sayuran secara hidroponik.

\section{Pemanenan dan Pengemasan Tanaman Sayuran Hidroponik}

Tanaman sayuran dipanen setelah 40 hari setelah tanam. Pemanenan sayuran hidroponik dilakukan serentak oleh para peserta pelatihan beserta pelaksana pelatihan (Gambar 6). Tanaman sayur yang siap dipanen secara umum cukup segar dan membuat peserta semakin tertarik untuk menerapkannya di pekarangan rumah. Masyarakat begitu antusias untuk memanen tanaman sawi hidroponik tanpa pestisida tersebut. Kegiatan selanjutnya adalah pengemasan sayur yang telah dipanen. Kegiatan ini bertujuan agar menarik perhatian masyarakat untuk belajar usaha sayuran hidroponik. Sayuran hidroponik merupakan salah satu prospek usaha pertanian yang ekslusif untuk dikembangkan.

\section{Analisis SWOT Kegiatan Budi Daya Sayuran Hidroponik}

Kegiatan pelatihan hidroponik tidak sepenuhnya diikuti oleh seluruh anggota PKK Pagarawan yang diundang dalam kegiatan tersebut. Hal itu terjadi karena adanya beberapa

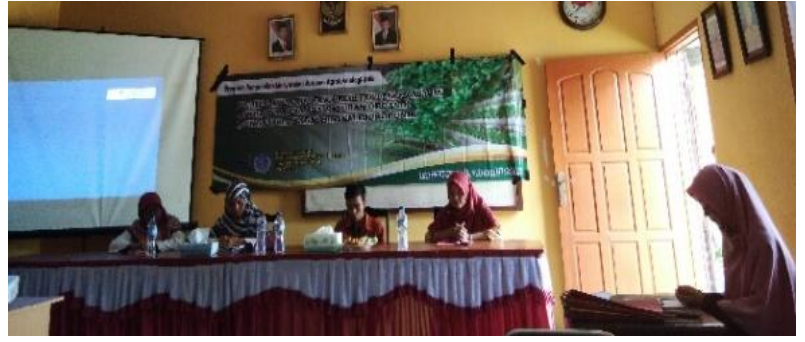

Gambar 2 Kegiatan penyuluhan tentang hidroponik.

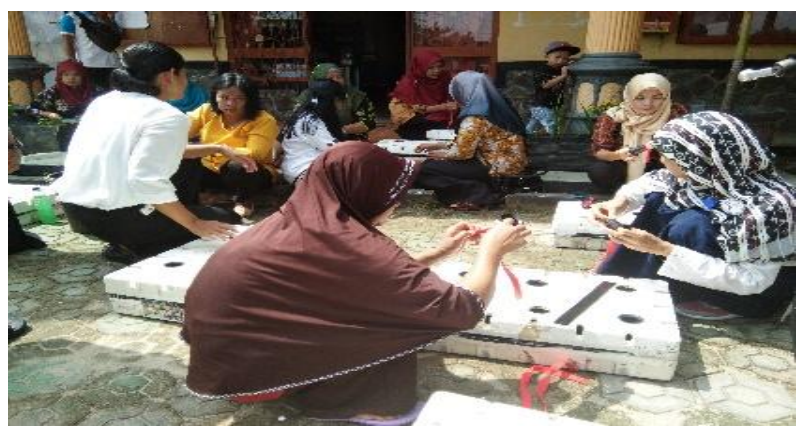

Gambar 3 Kegiatan pelatihan pembuatan media hidroponik.

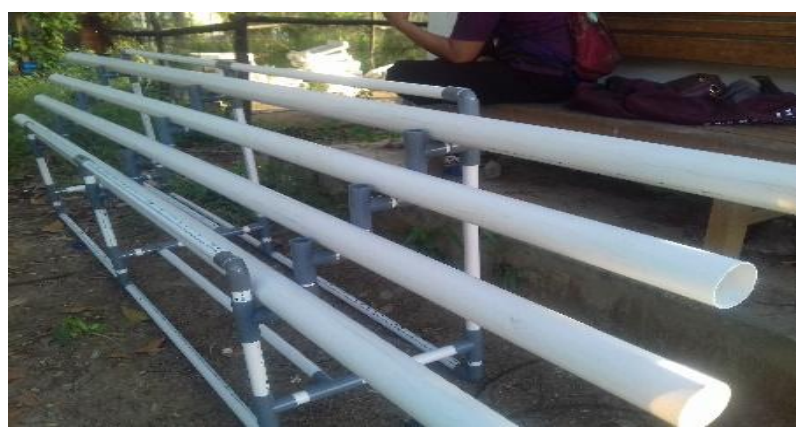

Gambar 4 Media penanaman hidroponik.

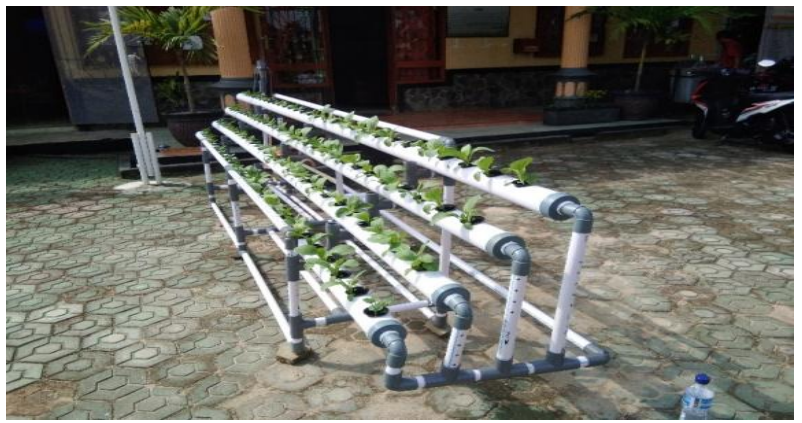

Gambar 5 Penanaman pada media hidroponik.

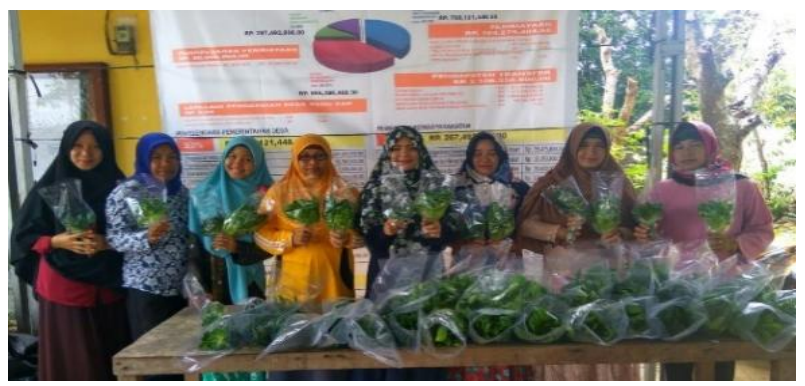

Gambar 6 Pemanenan tanaman hidroponik. 
kendala yang mengakibatkan sebagian kecil anggota tidak berpartisipasi. Kendala utama adalah ibu-ibu PKK memiliki kegiatan bekarja paruh waktu, menjemput anak-anak dari sekolah, dan menyelesaikan pekerjaan rumah tangga. Secara umum peserta pelatihan memberikan tanggapan yang positif akan kegiatan tersebut dan mereka mengharapkan dapat meneruskan keterampilan menanam hidroponik di rumah masing-masing.

Berdasarkan data kuesioner (Tabel 1) sebanyak $100 \%$ peserta menyatakan budi daya tanaman hidroponik penting dilakukan. Tanaman hidroponik lebih bersih dan bebas pestisida, cocok dikembangkan oleh masyarakat kota (lahan sempit). Tanaman hidroponik cocok dikembangkan oleh ibu rumah tangga untuk memenuhi kebutuhan sayuran sehari-hari. Seluruh peserta pelatihan menyatakan sangat setuju dan setuju untuk budi daya tanaman secara hidroponik. Hasil kuesioner yang diperoleh menunjukkan bahwa para peserta tertarik untuk mengembangkan tanaman hidroponik di rumah masing-masing.

Penerapan teknologi hidroponik di rumah masing-masing memang harus dilakukan oleh masyarakat di Pagarawan. Bertanam hidroponik memiliki keunggulan-keunggulan tertentu yang membuat masyarakat tertarik untuk mengembangkannya. Penerapan teknologi hidroponik ini pada awal kegiatan akan memerlukan modal besar. Kegiatan awal penerapan teknologi hidroponik ini harus dipilih faktor produksi yang bernilai tinggi, berkesinambungan memberikan pendapatan secara ekonomis dan tidak memerlukan modal besar di awalnya.

Hasil analisis SWOT menunjukkan keragaman dari kekuatan, kelemahan, ancaman, dan peluang dari pengembangan program budi daya tanaman hidroponik skala rumah tangga (Tabel 2). Kekuatan yang dimiliki oleh masyarakat petani yang akan mengembangkan teknologi hidroponik ialah tidak perlu lahan yang luas, keterampilan, tingkat ketertarikan masyarakat yang tinggi, adanya dukungan dari rumah tangga, dan pemantauan dari akademisi, dinas, dan aparat pemerintahan. Teknologi hidroponik yang diterapkan oleh masyarakat juga menjamin adanya pendapatan secara terus-menerus dari tanaman yang akan ditanam secara hidroponik.

Selain kekuatan juga ada kelemahan yang dimiliki oleh masyarakat, yaitu terutama segi permodalan yang dimiliki. Oleh karena itu, secara umum masyarakat kesulitan mengadakan bahanbahan yang diperlukan untuk menjalankan budi daya tanaman secara hidroponik. Kurangnya

Tabel 1 Hasil perhitungan kuesioner tanggapan masyarakat tentang budi daya tanaman secara hidroponik

\begin{tabular}{|c|c|c|c|c|c|}
\hline Pernyataan & $\begin{array}{l}\text { Sangat } \\
\text { setuju } \\
(\%)\end{array}$ & $\begin{array}{l}\text { Setuju } \\
(\%)\end{array}$ & $\begin{array}{c}\text { Kurang } \\
\text { memerhatikan } \\
(\%)\end{array}$ & $\begin{array}{l}\text { Tidak } \\
\text { setuju } \\
(\%)\end{array}$ & $\begin{array}{c}\text { Sangat } \\
\text { tidak } \\
\text { setuju (\%) }\end{array}$ \\
\hline $\begin{array}{l}\text { Apakah anda setuju jika budi daya tanaman } \\
\text { dilakukan secara hidroponik? }\end{array}$ & 38,46 & 61,54 & 0,00 & 0,00 & 0,00 \\
\hline $\begin{array}{l}\text { Teknik budi daya tanaman secara hidroponik } \\
\text { mudah dilakukan. }\end{array}$ & 7,69 & 76,92 & 0,00 & 15,38 & 0,00 \\
\hline $\begin{array}{l}\text { Budi daya tanaman secara hidroponik dapat } \\
\text { dijadikan usaha (bisnis). }\end{array}$ & 30,77 & 69,23 & 0,00 & 0,00 & 0,00 \\
\hline $\begin{array}{l}\text { Budi daya tanaman secara hidroponik } \\
\text { memerlukan biaya yang besar. }\end{array}$ & 0,00 & 30,77 & 15,38 & 53,85 & 0,00 \\
\hline $\begin{array}{l}\text { Tanaman hidroponik lebih sehat untuk } \\
\text { dikonsumsi dibandingkan dengan budi daya } \\
\text { di tanah. }\end{array}$ & 61,54 & 30,77 & 7,69 & 0,00 & 0,00 \\
\hline $\begin{array}{l}\text { Budi daya tanaman secara hidroponik masih } \\
\text { berbahaya karena menggunakan pupuk kimia } \\
\text { (anorganik). }\end{array}$ & 0,00 & 15,38 & 7,69 & 69,23 & 7,69 \\
\hline $\begin{array}{l}\text { Tanaman hasil budi daya hidroponik lebih } \\
\text { bersih dan bebas pestisida. }\end{array}$ & 38,46 & 61,54 & 0,00 & 0,00 & 0,00 \\
\hline $\begin{array}{l}\text { Sayuran hidroponik lebih cocok } \\
\text { dikembangkan oleh masyarakat kota (lahan } \\
\text { sempit). }\end{array}$ & 46,15 & 46,15 & 0,00 & 7,69 & 0,00 \\
\hline $\begin{array}{l}\text { Budi daya sayuran hidroponik cocok } \\
\text { dikembangkan oleh ibu rumah tangga untuk } \\
\text { memenuhi kebutuhan sayuran sehari-hari. }\end{array}$ & 46,15 & 53,85 & 0,00 & 0,00 & 0,00 \\
\hline $\begin{array}{l}\text { Apakah anda setuju mengembangkan } \\
\text { tanaman hidroponik di rumah anda. }\end{array}$ & 15,38 & 84,62 & 0,00 & 0,00 & 0,00 \\
\hline
\end{tabular}


Tabel 2 Analisis SWOT budi daya tanaman hidroponik di Desa Pagarawan

\begin{tabular}{|c|c|c|}
\hline Eksternal faktor & $\begin{array}{l}\text { Kekuatan } \\
\text { (strenght) } \\
\text { 1. Tersedianya lahan rumah masing- } \\
\text { masing. } \\
\text { 2. Keterampilan bidang hidroponik. } \\
\text { 3. Mendapatkan pendapatan secara } \\
\text { terus-menerus. } \\
\text { 4. Dukungan dari rumah tangga, } \\
\text { akademisi, dinas dan aparat } \\
\text { pemerintahan } \\
\text { 5. Tingkat ketertarikan masyarakat yang } \\
\text { tinggi. }\end{array}$ & $\begin{array}{l}\text { Kelemahan } \\
\text { (weakness) } \\
\text { 1. Kemampuan permodalan yang } \\
\text { rendah } \\
\text { 2. Minimnya ketersediaan alat dan } \\
\text { bahan yang diperlukan. } \\
\text { 3. Adanya masyarakat yang kurang } \\
\text { memerhatikan informasi } \\
\text { mengenai hidroponik. } \\
\text { 4. Hanya cocok dikembangkan di } \\
\text { daerah kota minim lahan } \\
\text { pertanian. }\end{array}$ \\
\hline $\begin{array}{l}\text { Peluang } \\
\text { (opportunity) } \\
\text { 1. Kebutuhan masyarakat } \\
\text { akan produk pertanian } \\
\text { 2. Tingkat persaingan } \\
\text { masih rendah } \\
\text { 3. Kemampuan } \\
\text { masyarakat lain di } \\
\text { bidang teknologi } \\
\text { hidroponik yang } \\
\text { rendah } \\
\text { 4. Mahalnya harga produk } \\
\text { tanaman hidroponik } \\
\text { 5. Adanya jalinan kerja } \\
\text { sama antar keluarga di } \\
\text { jumah, akademisi, dan } \\
\text { pemerintah. }\end{array}$ & $\begin{array}{l}\text { Kekuatan-Peluang (SO) } \\
\text { 1. Tersedianya lahan rumah masing- } \\
\text { masing,dukungan dari rumah tangga, } \\
\text { akademisi, dan pemerintah } \\
\text { merupakan modal pengembangan } \\
\text { kemampuan masyarakat dalam } \\
\text { bertanam secara hidroponik (S1,4:03) } \\
\text { 2. Kebutuhan masyarakat akan produk } \\
\text { pertanian dan harganya yang tinggi } \\
\text { akan memberikan keuntungan terus- } \\
\text { menerus (01:S3) dimiliki } \\
\text { 3. Keterampilan yang lain } \\
\text { masyarakat dengan rendahnya } \\
\text { kemampuan masyarakat } \\
\text { menyebabkan harga produk tinggi } \\
\text { karena rendahnya persaingan } \\
(03,4: S 2)\end{array}$ & $\begin{array}{l}\text { Mekuatan-Ancaman (ST) } \\
\text { 1. Perlu ada keterampilan tinggi } \\
\text { untuk meningkatkan persentase } \\
\text { keberhasilan bertanam hidroponik } \\
\text { karena adanya kesibukan lainnya } \\
\text { (pekerjaan harian) selain } \\
\text { bertanam (S2,3:T1,3) } \\
\text { 2. Adanya dukungan dari rumah } \\
\text { tangga, akademisi, dan pemerintah } \\
\text { dapat memperdalam pengetahuan } \\
\text { mengenai budi daya hidroponik } \\
\text { (S4:T4) }\end{array}$ \\
\hline $\begin{array}{l}\text { Ancaman } \\
\text { (threat) } \\
\text { 1. Masih adanya } \\
\text { perkerjaan harian. } \\
\text { 2. Adanya organisme } \\
\text { pengganggu tanaman } \\
\text { yang berasal dari } \\
\text { tanaman lain di sekitar } \\
\text { rumah. } \\
\text { 3. Tidak adanya kepastian } \\
\text { keberhasilan bertanam } \\
\text { hidroponik. } \\
\text { 4. Kurang pengetahuan } \\
\text { yang mendalam } \\
\text { mengenai budidaya } \\
\text { secara hidroponik. }\end{array}$ & $\begin{array}{l}\text { Kelemahan-Peluang (WO) } \\
\text { 1. Kebutuhan masyarakat yang tinggi } \\
\text { akan produk pertanian dan harganya } \\
\text { yang relatif mahal merupakan masalah } \\
\text { yang harus dipecahkan melalui } \\
\text { diadakannya alat dan bahan yang } \\
\text { diperlukan untuk pengadaan produk } \\
\text { hidroponik (01,4:W2) } \\
\text { 2. Permodalan bagi masyarakat dalam } \\
\text { mengembangkan produk harus } \\
\text { diadakan mengingat masih sedikitnya } \\
\text { masyarakat yang dan mampu } \\
\text { mengembangkan tingkat } \\
\text { persaingan yang rendah akan } \\
\text { memberikan keuntungan yang optimal } \\
\text { (02,3:W2) }\end{array}$ & $\begin{array}{l}\text { Kelemahan-Ancaman (WT) } \\
\text { 1. Perlu adanya peningkatan } \\
\text { perhatian masyarakat tentang } \\
\text { informasi hidroponik karena } \\
\text { masih adanya organisme } \\
\text { pengganggu tanaman di sekitar } \\
\text { rumah akibat kurangnya } \\
\text { pengetahuan (W3:T2,4) } \\
\text { 2. Harus ada ketersediaan alat dan } \\
\text { bahan hidroponik yang menjamin } \\
\text { tingkat keberhasilan bertanam } \\
\text { hidroponik (W2:T3) } \\
\text { 3. Minimnya bahan dan sarana } \\
\text { produksi harus segera diatasi } \\
\text { bersama sehingga dapat } \\
\text { meringankan beban dibalik adanya } \\
\text { pekerjaan (W2: T1,4) }\end{array}$ \\
\hline
\end{tabular}

pengetahuan teknik budi daya hidroponik dapat menurunkan hasil. Kelemahan-kelemahan dalam budi daya tanaman secara hidroponik dapat dijadikan sebagai peluang usaha (atau bisnis. Hasil kegiatan pengabdian yang dilakukan Mardina et al. (2019) di Gampong Sidorejo, Langsa Aceh memberikan manfaat positif, yaitu bertanam sistem hidroponik dapat dijadikan sarana penyaluran hobi, kesehatan, dan dapat dikembangkan menjadi skala bisnis.
Ancaman yang ada dalam kegiatan adalah masih adanya pekerjaan harian yang dilakukan oleh masyarakat setiap harinya, sehingga harus bisa membagi waktu. Adanya organisme pengganggu tanaman yang berasal dari tanaman lain di rumah. Tidak adanya kepastian keberhasilan bertanam hidroponik. Kurang pengetahuan yang mendalam mengenai budi daya secara hidroponik. 
Peluang untuk melaksanakan budi daya hidroponik ini sebenarnya cukup besar terutama dari segi perhitungan keuntungan. Adanya pengetahuan, keterampilan, ketersediaan alat, bahan, serta waktu yang optimal dapat dilaksanakan budi daya tanaman secara hidroponik ini. Keuntungan secara ekonomi akan diperoleh masyarakat karena kebutuhan masyarakat akan produk hidroponik akan selalu ada. Kemampuan masyarakat di Bangka akan penerapan bidang produksi pertanian yang masih rendah menyebabkan harga produk pertanian relatif mahal. Persaingan antar-petani, tengkulak, dan pedagang ecer sendiri dapat dikatakan rendah.

Berdasarkan hasil analisis SWOT ada beberapa langkah yang harus dilakukan untuk mengembangkan budi daya tanaman secara hidroponik di Desa Pagarawan. Langkah-langkah tersebut meliputi:

- Harus ada pengetahuan dan keterampilan yang tinggi untuk masyarakat dalam bertanam secara hidroponik. Masyarakat yang kurang pengetahuan dapat mengakibatkan tingkat keberhasilan bertanam hidroponik yang rendah.

- Perlu adanya kerja sama bersama akademisi dan pemerintah dalam meningkatkan keterampilan dan pengetahuan mengenai bertanam hidroponik. Akademisi memiliki pembelajaran yang sering diperoleh di tempat belajarnya, dan pemerintah memiliki informasi-informasi peluang dalam mengembangkan tanaman hidroponik.

- Permodalan masyarakat perlu diatur dengan baik dengan cara memberikan contoh hidroponik sederhana terlebih dahulu sebelum ke contoh yang memerlukan investasi biaya yang tinggi.

- Adanya jaminan dari sebuah hasil penelitian terpadu tentang keamanan pangan produk tanaman yang ditanam secara hidroponik bebas pestisida namun menggunakan pupuk kimia.

- Perlu dikembangkan mekanisme pemasaran produk tanaman hidroponik yang memberikan keuntungan optimal kepada masyarakat yang ingin usaha (bisnis), namun tidak merugikan konsumen produk tanaman hidroponik. Adanya jaminan keuntungan bagi masyarakat yang membuka usaha (bisnis) dan konsumen menuju kemandirian produk tanaman hidroponik di Desa Pagarawan.

\section{Analisis Usaha Tani Kegiatan Budi Daya Sayuran Hidroponik}

Tanaman yang dibudidayakan secara hidroponik memiliki biaya yang cukup besar per satuannya, walaupun demikian usaha tanaman sayur hidroponik ternyata cukup menguntungkan. Keuntungan yang diraih lebih banyak dibandingkan dengan budi daya konvensional di tanah. Hal tersebut dibuktikan pada perhitungan analisis usaha tani dari tanaman sawi yang ditanam secara hidroponik.

Biaya investasi yang diperlukan adalah $\mathrm{Rp}$ 2.016.000 biaya operasional per bulan tetap adalah Rp 34.664,21 dan variabel Rp 208.000,00. Penghasilan yang didapatkan per bulan adalah Rp 769.500,00. Keuntungan diperoleh setiap bulannya sebesar Rp 502.570. Hasil yang diperoleh tersebut berarti usaha akan impas pada hasil penjualan sebesar Rp 47.505,09/ waktu tanam/2 bulan. Harga penjualan minimal dapat diketahui dengan membagi BEP dengan jumlah produksi. Produksi standar tanaman sawi $0,2 \mathrm{~kg} /$ tanaman dan jumlah tanaman 270 maka harga penjualan minimal $\mathrm{Rp} 47.505,09 /(0,2 \mathrm{x}$ $270)=\mathrm{Rp} 879,72 / \mathrm{kg}$. Harga jual tanaman sawi Rp $15.000 / \mathrm{kg}$ maka jumlah produksi minimalnya $\mathrm{Rp}$ $47.505,09 / \mathrm{Rp} 15.000=3,17 \mathrm{~kg}$ untuk 270 tanaman, atau per tanamannya menghasilkan sebanyak 0,014 kg atau setara dengan $14 \mathrm{~g}$. Data di atas berarti bila ingin mendapatkan keuntungan, harga jual harus di atas $\mathrm{Rp}$ $879,72 / \mathrm{kg}$ untuk produksi sebanyak $54 \mathrm{~kg}$, atau dengan jumlah produksi di atas 0,014 $\mathrm{kg} /$ tanaman bila harga jualnya sebesar $\mathrm{Rp}$ $15.000 / \mathrm{kg}$.

\section{SIMPULAN}

Masyarakat telah mengetahui cara budi daya sayuran organik bebas pestisida secara hidroponik terutama penerapan di perkarangan rumah sehingga memudahkan dalam memperoleh tanaman jenis sayuran yang bebas pestisida. Peserta pelatihan sangat setuju terhadap budi daya tanaman sayuran secara hidroponik dibuktikan dengan sebanyak 38,46\% peserta sangat setuju, $61,54 \%$ setuju, dan $0 \%$ tidak setuju terhadap budi daya tanaman dilakukan secara hidroponik. Masyarakat tetap menyakini untuk mengembangkan budi daya tanaman secara hidroponik, walaupun ada berbagai kelemahan yang masih tersedia dalam budi daya hidroponik. Peluang bisnis tanaman 
hidroponik baik untuk dikembangkan, hal tersebut dibuktikan dari hasil analisis usaha tani dengan biaya investasi sebesar Rp 2.016.000 dapat memperoleh keuntungan sebesar Rp 502.570 setiap bulannya. Perlunya pengembangan perekonomian masyarakat dengan cara membuat usaha sayuran organik secara hidroponik oleh individu masyarakat Desa Pagarawan. Akademisi dan pemerintah diharapkan dapat mendukung pengembangan hidroponik yang dilakukan masyarakat Desa Pagarawan.

\section{UCAPAN TERIMA KASIH}

Ucapan terima kasih disampaikan kepada Universitas Bangka Belitung (UBB) dan Lembaga Penelitian dan Pengabdian Masyarakat (LPPM) yang telah memberikan pendanaan kegiatan pengabdian masyarakat ini pada tahun anggaran 2018.

\section{DAFTAR PUSTAKA}

Azizah UN. 2009. Pengaruh Media Tanaman dan Jenis Pupuk terhadap Pertumbuhan dan Perkembangan Tanaman Tomat (Lycopersicum esculentum Mill.) dengan Teknik Budidaya Sistem Hidroponik. [Thesis]. Malang (ID): Universitas Islam Maulana Malik Ibrahim.

[BPS] Badan Pusat Statistik. 2016. Banyaknya Keluarga Pra Sejahtera dan Sejahtera menurut Kecamatan, 2015. [Internet]. [Diakses pada 13 Agustus 2018]. Tersedia pada: http://www.bps.go.id.

Desa Pangrawan. 2018. Profil Desa Pagarawan. [Internet]. [Diakses pada: 13 Agustus 2018]. Tersedia pada: http://pagarawan.desa.id/ sejarah-desa/.
Haryanto ET, Suhartini, Rahayu E. 2002. Sawi dan Selada. Jakarta (ID): Penebar Swadaya.

Mardina V, Fitriani, Muslimah. 2019. Sosialisasi Sistem Penanaman Hidroponik Limbah Tebu di Gampong Sidorejo, Langsa, Aceh. Agrokreatif Jurnal Ilmiah Pengabdian kepada Masyarakat. $\quad 5(2): \quad$ 135-140. https://doi.org/10.29244/agrokreatif.5.2.13 5-140

Putra RM. 2018. Budi daya Tanaman Hidroponik DFT pada Tiga Kondisi Nutrisi yang Berbeda. [Skripsi]. Lampung (ID): Universitas Lampung.

Rahimah DS. 2012. Hidroponik di Bawah Langit. TRUBUS No. 513 Edisi Agustus 2012/XLIII.

Resh HM. 2013. Hydroponic Food Production, A Definitive Guidebook for the Advanced Home Gardener and the Commercial Hydroponic Grower. New York (US): CRC Press.

Roidah IS. 2014. Pemanfaatan Lahan Dengan Menggunakan Sistem Hidroponik. Jurnal Universitas Tulungagung Bonorowo. 1(2): 4350.

Sameto H. 2005. Hidroponik Sederhana Penyejuk Ruangan. Jakarta (ID): Penebar Swadaya.

Susila AD. 2013. Sistem Hidroponik. Modul Matakuliah Dasar Dasar Hortikultura Fakultas Pertanian. Bogor (ID): Institut Pertanian Bogor.

Swastika S, Yulfida A, Sumitro Y. 2018. Buku Petunjuk Teknis Budidaya Sayuran Hidroponik (Bertanam Tanpa Media Tanah). Riau (ID): Balai Pengkajian Teknologi Pertanian (BPTP) Balitbangtan Riau, Badan Penelitian dan Pengembangan Pertanian, Kementerian Pertanian.

Tim Karya Tani Mandiri. 2010. Pedoman Budidaya Secara Hidroponik. Bandung (ID): Nuansa Aulia. 